\title{
Vertical particle flux on the shelf off northern Spitsbergen, Norway
}

\author{
I. Andreassen ${ }^{1, *}$, E.-M. Nöthig ${ }^{2}$, P. Wassmann ${ }^{1}$ \\ ${ }^{1}$ Norwegian College of Fishery Science, University of Tromse, N-9037 Tromse, Norway \\ ${ }^{2}$ Alfred Wegener Institute for Polar and Marine Research, Am Handelshaven 12, D-27570 Bremerhaven, Germany
}

\begin{abstract}
Suspended and sedimented particulate matter was examined along transects on the continental shelf off northern Spitsbergen, Norway, during summer 1991 The transects were situated in non-ice-covered areas dominated by Atlantic water, areas with multi-year ice and the marginal ice zone. The variability of the sedimented matter with regard to composition, quantity and quality between the 7 investigated stations was considerable. The open Atlantic water showed the highest suspended biomass 1100 to $280 \mathrm{mg}$ particulate organic carbon (POC) $\mathrm{m}^{-3}$ and the vertical flux was mod-

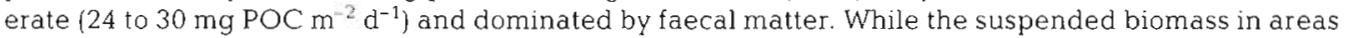
covered by multi-year ice was low $\left(<65 \mathrm{mg} \mathrm{POC}^{-3}\right)$, the vertical flux was relatively high (18 to $76 \mathrm{mg}$ POC $\mathrm{m}^{-2} \mathrm{~d}^{-1}$ ) and dominated by terrestrial organic and faecal matter. The contribution of phytoplankton cells to the vertical flux of POC was small in areas covered by multi-year ice, on average about $1 \%$. The contribution of phytoplankton cells to the vertical flux in the marginal ice zone was higher ( $5.6 \%$ of POC), consisting mainly of Chaetoceros socialis and Fragilariopsis sp., but a considerable amount of faecal matter also settled. At all stations zooplankton strongly influenced the vertical flux, not only by faecal pellet production but probably also by direct mediation of fluxes (e.g. coprophagy).
\end{abstract}

KEY WORDS: Vertical flux $\cdot$ Arctic Ocean $\cdot$ Faecal pellets $\cdot$ Spring bloom

\section{INTRODUCTION}

For arctic waters to be a true sink of atmospheric $\mathrm{CO}_{2}$ a large proportion of the carbon must become inaccessible to the atmosphere (Sarmiento \& Toggweiler 1984, Anderson et al. 1990). This can be caused by deep water formation, but can also occur if carbon fixation by photosynthesis decreases the $\mathrm{pCO}_{2}$ in the surface water (Takahashi et al. 1993) and the carbon sinks to intermediate depths in particulate form (e.g. Bodungen et al. 1995). If most of the carbon fixed is recycled close to the ocean surface, it can diffuse back to the atmosphere. Loss of organic matter from surface waters takes place through settling of phytoplankton cells, faecal pellets produced by zooplankton and plankton-derived detritus. Highly silicified phytoplankton species such as diatoms sink faster than fla-

•E-mail: ingera@nfh.uit.no gellates (Smayda 1970), and several diatom species form aggregates, which greatly increases the sinking speed of the cells (Passow et al. 1994). Together with faecal pellets, aggregates are expected to be major contributors of organic matter to the sediments. The resultant vertical flux to the sediments is therefore not only a function of the total primary production, but also of the type of phytoplankton and grazers present in the system.

Studies of the vertical flux of particulate matter have revealed major differences with regard to the quantity and composition of the material exported from the upper layers, as well as seasonal and inter-annual differences. Investigations in polar and ice-covered waters have mainly been confined to Antarctica (e.g. Fischer et al. 1988, Nöthig \& Bodungen 1989, Bathmann et al. 1991, Riebesell et al. 1991). In the Arctic, investigations have been carried out in ice-covered shelf waters such as the Beaufort Sea (Carey 1987), the 


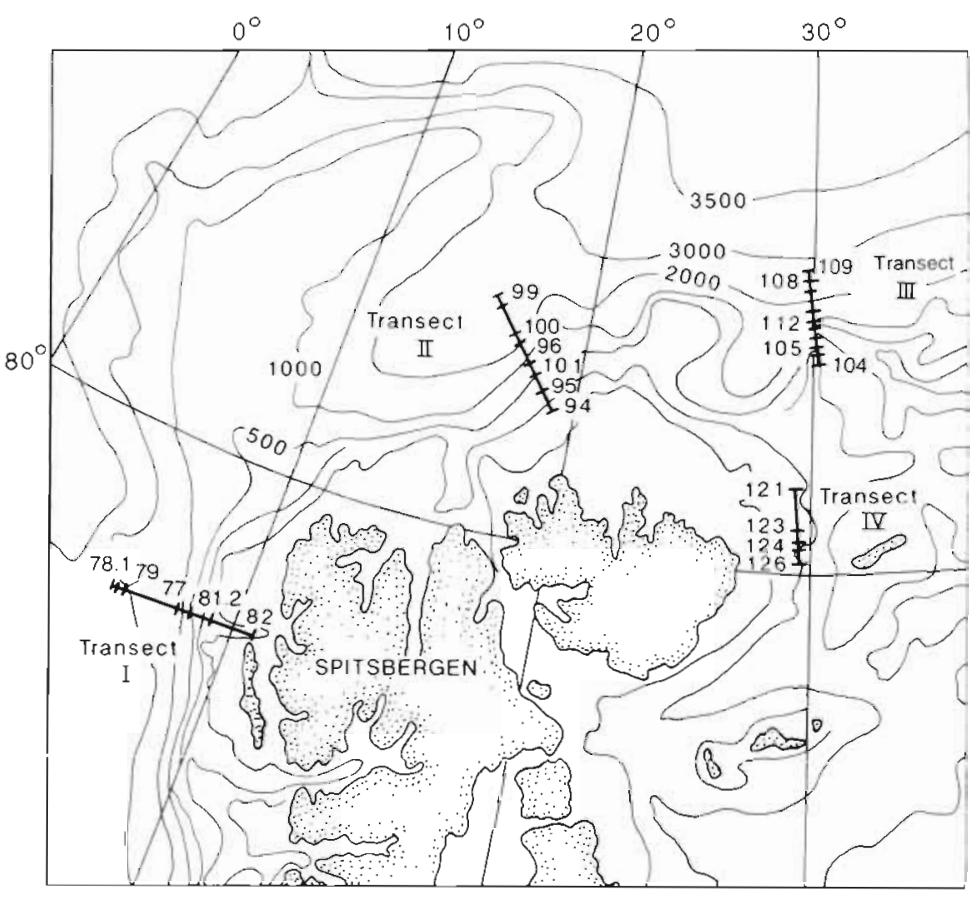

Fig. 1 Locations of transects and stations on the shelf off Spitsbergen, Norway

Canadian Arctic (Hsiao 1987, Hargrave et al. 1994), the Bering Sea and Gulf of Alaska (Iseki 1981) and Hudson Bay (Tremblay et al. 1989, Michel et al. 1993). In the polar and sub-polar northeast Atlantic Ocean studies of vertical flux have been carried out in the Norwegian Sea (e.g. Honjo et al. 1988, Bathmann et al. 1990 ) and in the marginal ice zone (MIZ) of the central Barents Sea (e.g. Wassmann et al. 1990, 1991). Longterm investigations of vertical flux in non-permanently ice-covered waters have been carried out with deepmoored traps in waters dominated by the West Spitsbergen Current and in the Fram Strait (e.g. Honjo et al. 1987. Hebbeln \& Wefer 1991).

No observations of the vertical flux of particulate matter in the seasonal and permanently ice-covered waters north of Spitsbergen have been conducted so far. The present study presents some initial results from this area with regard to pelagic-benthic coupling and compares suspended biomass and vertical flux on the shelf off northern Spitsbergen. This study was part of the 'Study of the Arctic Shelf' (SEAS) program, which has the goal of carrying out multi-disciplinary investigations of pelagic and benthic processes on the shelf areas fringing the Arctic Ocean. Our investigation aimed to characterise (a) the composition, quality and quantity of the suspended particles, (b) the magnitude of the vertical flux, (c) the composition, quality and the source of sinking particles and (d) the processes controlling the vertical flux.

\section{MATERIAL AND METHODS}

Data were collected in the shelf seas off northern Spitsbergen during the period June 20 to July 30, 1991 The measurements were carried out during EPOS (European Polarstern Study) II, on board the German RV 'Polarstern'. Samples were taken in 3 main areas: Transect I in open Atlantic water northwest of Spitsbergen; Transects II and III in areas covered with multi-year ice north of Spitsbergen; and Transect IV in the MIZ northeast of Spitsbergen (Fig. 1)

Hydrographic profiles were obtained with a Neil Brown CTD-profiler mounted on a General Oceanic rosette with twenty-four 12 l Niskin bottles. Samples for suspended biomass Iparticulate carbon and nitrogen (POC and PON), total particulate matter (TPM), particulate silicate (PSi) and pigments-chlorophyll a (chl a) and phaeopigments (phaeo)] were collected from 4 to 10 depths at various stations. Sampling depths were selected on the basis of salinity, temperature and in vivo fluorescence (Backscat). Samples of 0.5 to 2 l were filtered on pre-combusted Whatman $\mathrm{GF} / \mathrm{C}$ filters for POC, PON and pigments, on Sartorius $0.8 \mu \mathrm{m}$ celluloseacetate filters for PSi and on pre-weighed GF/C filters for TPM. The filters for TPM were rinsed with distilled water after filtration to remove salt. Copepods were removed from all filters by means of forceps. Samples for chl $a$ and phaeo were processed immediately after sampling and the rest of the samples were stored in a freezer prior to analysis.

Vertical flux of particulate matter was measured using a TECNICAP P.P.S. 3/3 cylindrical trap with $40 \mathrm{~cm}$ diameter and $190 \mathrm{~cm}$ height. The trap had a conical bottom which ended in a $250 \mathrm{ml}$ sample jar (Fig. 2C). The positions of the trap deployments are given in Table 1 and are depicted in Fig. 1. The trap was deployed using a drifting buoy in open waters. In ice-covered areas the trap was deployed at ice floes (Fig. 2A, B). The depth of deployment was $100 \mathrm{~m}$ for all stations except $\operatorname{Stn} 124$ where the trap was deployed at $60 \mathrm{~m}$ due to an underwater ridge in the area. The duration of the deployments varied between 8 and $24 \mathrm{~h}$ (Table 1). After recovery the trap remained untouched on deck for $2 \mathrm{~h}$ to allow material which may have been resuspended during recovery to settle. After $2 \mathrm{~h}$ the water in the cylinder was siphoned off and the sample jar retrieved.

Samples from the sediment trap were split with a bird pipette and $25 \mathrm{ml}$ sub-samples for TPM, POC, PON, PSi, chl a and phaeo were taken. These subsamples were filtered as described above for water samples. 
Subsamples for microscopic examination were fixed with buffered formaldehyde $(0.4 \%$ final concentration). Samples for chl a and phaeo were analysed on board using a Turner fluorometer (Holm-Hansen et al. 1965). The remaining samples were analysed on shore. POC and PON were analysed using a Leeman Lab CEC 440 CHN analyser after removal of carbonate with fumes of concentrated $\mathrm{HCl}$. PSi was dissolved using $0.1 \mathrm{M} \mathrm{NaOH}$ and heated to $85^{\circ} \mathrm{C}$ for $2 \mathrm{~h}$. The solution was buffered with diluted $\mathrm{H}_{2} \mathrm{SO}_{4}$ and analysed as dissolved silicate according to Grasshoff (1976). Samples for TPM were dried at $60^{\circ} \mathrm{C}$ overnight and weighed.

A minimum of 50 to 100 cells of the dominant species or groups in sediment trap samples were counted in $10 \mathrm{ml}$ aliquots that had been allowed to settle for $24 \mathrm{~h}$. Cell size was measured to calculate the cell volume and carbon content according to Edler (1979). When one or a few species dominated the sample, cells were counted at the species level, but most cells were counted in size classes corresponding to higher taxonomic levels. The following terms have been selected to describe the dominant phytoplankton groups in the sedimented material: centric and pennate diatoms, dinoflagellates, flagellates and ciliates. It was not possible to distinguish between heterotrophic and autotrophic dinoflagellates and flagellates. All cell counts except those for ciliates were used for calculating phytoplankton carbon (PPC), which hence is an overestimate since heterotrophic cells are incorporated in the count. Faecal pellets were counted and mea-

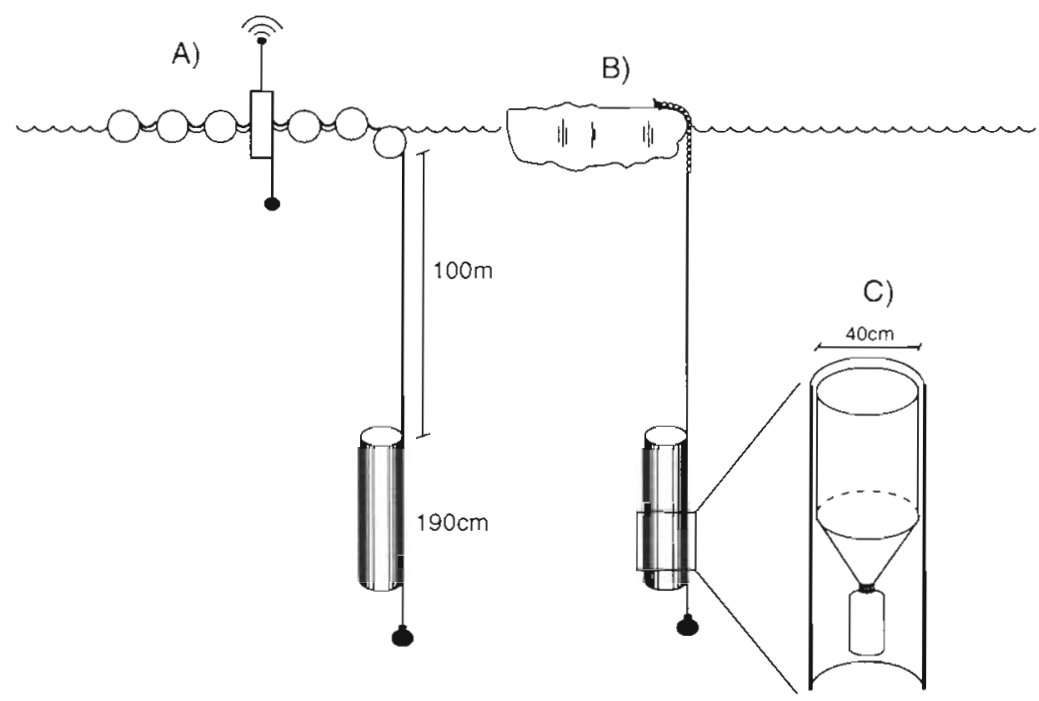

Fig. 2. Deployment of sediment trap: (A) in open water and (B) in ice-covered water. (C) Note the conical shape of the bottom of the trap leading to the sampling jar

sured, and their volume calculated. Both intact faecal pellets and pieces of faecal pellets were counted. Due to problems of identification, broken or destroyed faeces may not have been taken into account. The volume of faecal pellets is therefore probably underestimated. To calculate the faecal pellet carbon content (FPC), factors obtained from faecal pellets collected during the cruise (González \& Smetacek 1994) were used. These

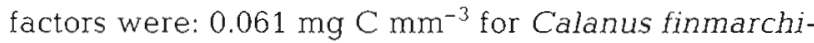
cus, which was used for all cylindrical pellets in Transect I, $0.038 \mathrm{mg} \mathrm{C} \mathrm{mm}^{-3}$ for Calanus glacialis, which was used for all cylindrical faecal pellets in Transects II, III, and IV; and $0.029 \mathrm{mg} \mathrm{C} \mathrm{mm}^{-3}$ for Oikopleura sp., which was used for the ellipsoid pellets in all transects.

Table 1. Deployment positions of sediment trap

\begin{tabular}{|c|c|c|c|c|c|c|}
\hline Transect & Station & Duration (h) & $\begin{array}{l}\text { Date } \\
(1991)\end{array}$ & $\begin{array}{c}\text { Position } \\
\text { (deployment, recovery) }\end{array}$ & $\begin{array}{l}\text { Depth } \\
(\mathrm{m})\end{array}$ & Mode of deployment \\
\hline \multirow[t]{2}{*}{ I } & 78 & 8.0 & 2 July & $\begin{array}{l}78^{\circ} 59^{\prime} \mathrm{N} 06^{\circ} 01^{\prime} \mathrm{E} \\
79^{\circ} 02^{\prime} \mathrm{N} 05^{\circ} 40^{\prime} \mathrm{E}\end{array}$ & 100 & Drifter \\
\hline & 81 & 9.0 & 4 July & $\begin{array}{l}79^{\circ} 01^{\prime} \mathrm{N} 08^{\circ} 35^{\prime} \mathrm{E}_{1} \\
79^{\circ} 05^{\prime} \mathrm{N} 08^{\circ} 46^{\prime} \mathrm{E}\end{array}$ & 100 & Drifter \\
\hline II & 101 & 13.0 & 11 July & $\begin{array}{l}81^{\circ} 17^{\prime} \mathrm{N} 18^{\circ} 37^{\prime} \mathrm{E} \\
81^{\circ} 12^{\prime} \mathrm{N} 18^{\circ} 42^{\prime} \mathrm{E}\end{array}$ & 100 & Moored to ice floe \\
\hline \multirow[t]{3}{*}{ III } & 108 & 12.5 & 16 July & $\begin{array}{l}81^{\circ} 40^{\prime} \mathrm{N} 29^{\circ} 48^{\prime} \mathrm{E} \\
81^{\circ} 40^{\prime} \mathrm{N} 30^{\circ} 00^{\prime} \mathrm{E}\end{array}$ & 100 & Moored to ice floe \\
\hline & 112 & 20.0 & 18 July & $\begin{array}{l}81^{\circ} 32^{\prime} \mathrm{N} 30^{\circ} 35^{\prime} \mathrm{E} \\
81^{\circ} 32^{\prime} \mathrm{N} 30^{\circ} 58^{\prime} \mathrm{E}\end{array}$ & 100 & Moored to ice floe \\
\hline & 105 & 20.5 & 15 July & $\begin{array}{l}81^{\circ} 26^{\prime} \mathrm{N} 30^{\circ} 55^{\prime} \mathrm{E} \\
61^{\circ} 20^{\prime} \times 30^{\circ} 55^{\prime} \mathrm{E}\end{array}$ & 100 & Moored to ice floe \\
\hline IV & 124 & 24.0 & 22 July & $\begin{array}{l}80^{\circ} 20^{\prime} \mathrm{N} 29^{\circ} 09^{\prime} \mathrm{E} \\
80^{\circ} 21^{\prime} \mathrm{N} 29^{\circ} 24^{\prime} \mathrm{E}\end{array}$ & 60 & Moored to ice floe \\
\hline
\end{tabular}




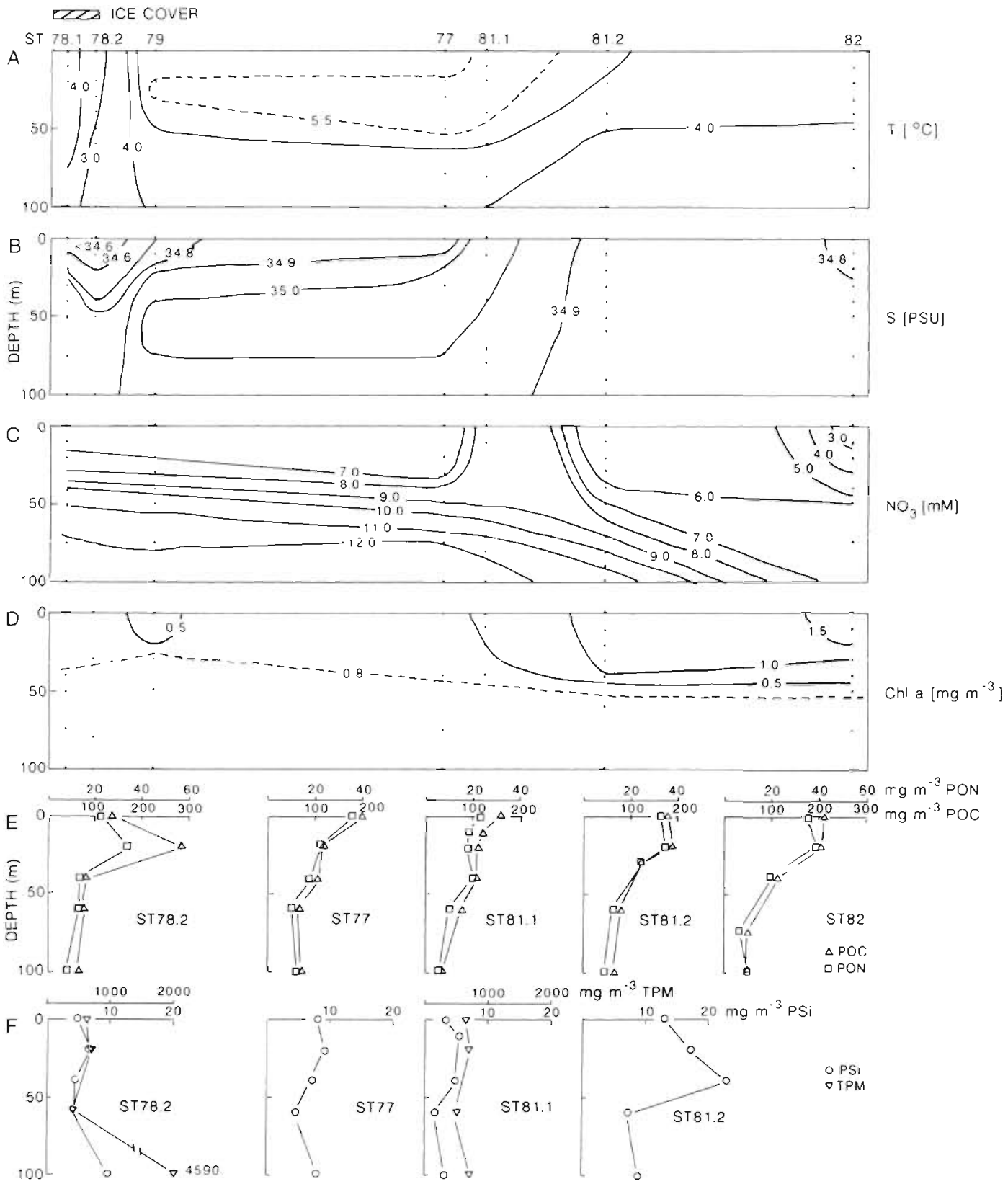

Fig. 3. Variability of (A) temperature, (B) salinity, (C) nitrate and (D) chl $a$ in the upper $100 \mathrm{~m}$ of Transect I. Also shown are vertical profiles of (E) POC and PON, and (F) TPM and PSi

\section{RESULTS}

\section{Hydrography, nutrients and suspended matter}

Open water (Transect I). The central section of Transect I was dominated by Atlantic water from the West Spitsbergen Current (WSC), At Stns 78.1, 78.2 and 79 (Fig. 3) melting drift ice in the area gave rise to a lens of melt water. The stations closest to land were domi- nated by slightly colder and less saline water from the West Spitsbergen Coastal Current (WSCC). Elevated concentrations of POC (110 to $\left.280 \mathrm{mg} \mathrm{m}^{-3}\right)$ and PON (13 to $38 \mathrm{mg} \mathrm{m}^{-3}$ ) were recorded in the upper $40 \mathrm{~m}$ at all stations. Concentrations of chl a were highest at the stations closest to land $\left(>1 \mathrm{mg} \mathrm{m}^{-3}\right)$ in the WSCC. In spite of the stabilisation of the water column due to the melt water, no developed spring bloom situation was recorded at Stns 78.1 and 78.2. This is reflected by low 

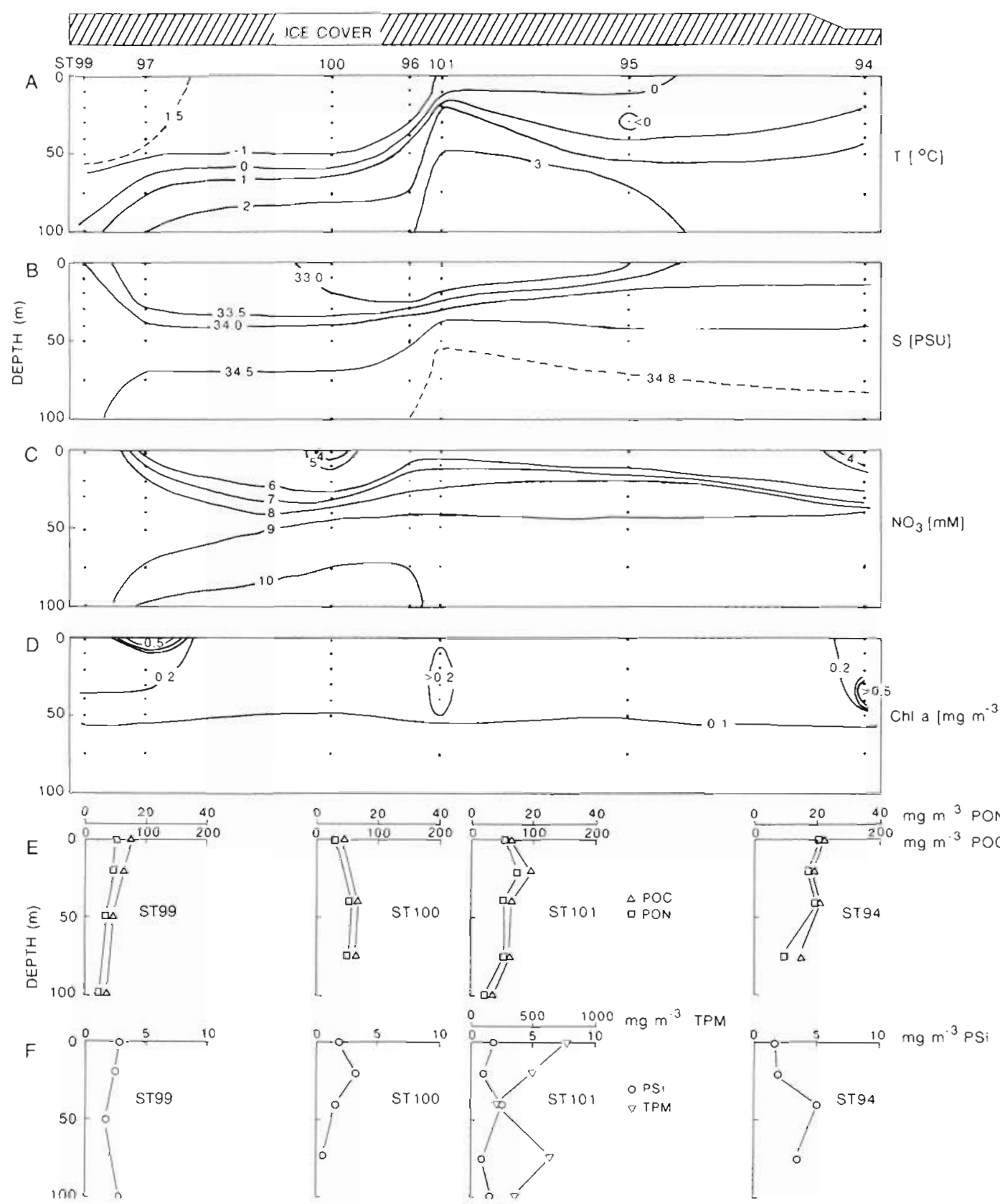

Fig. 4. Variability of (A) temperature, (B) salinity, (C) nitrate and (D) chl a in the upper $100 \mathrm{~m}$ of Transect II. Also shown are vertical profiles of (E) POC and PON, and (F) TPM and PSi

biomass and the generally high nutrient concentrations (Fig. 3).

Multi-year ice (Transects II and III). Atlantic water from the WSC was recognised below $50 \mathrm{~m}$ depth north of Spitsbergen in areas covered by multi-year ice, but the surface water was dominated bv Arctic water (Figs. $4 \& 5$ ). The concentrations of suspended organic matter at the stations covered by multi-year ice (Stns 101 to 112) were low. Chl a concentrations were lower than $0.5 \mathrm{mg} \mathrm{m}^{-3}$ and vertical profiles of POC, PON and PSi revealed small variations in concentration over the entire water column (36-92, 4-15 and $0.8-3.2 \mathrm{mg} \mathrm{m}^{-3}$, respectively). Elevated concentrations of TPM were recorded at Stns 112 and 105.

Marginal ice zone (Transect IV). This transect was dominated by Arctic water (Fig, 6). From Stn 124.2 southwards the surface water was influenced by melt water. At Stn 126 the influence of melt water was 

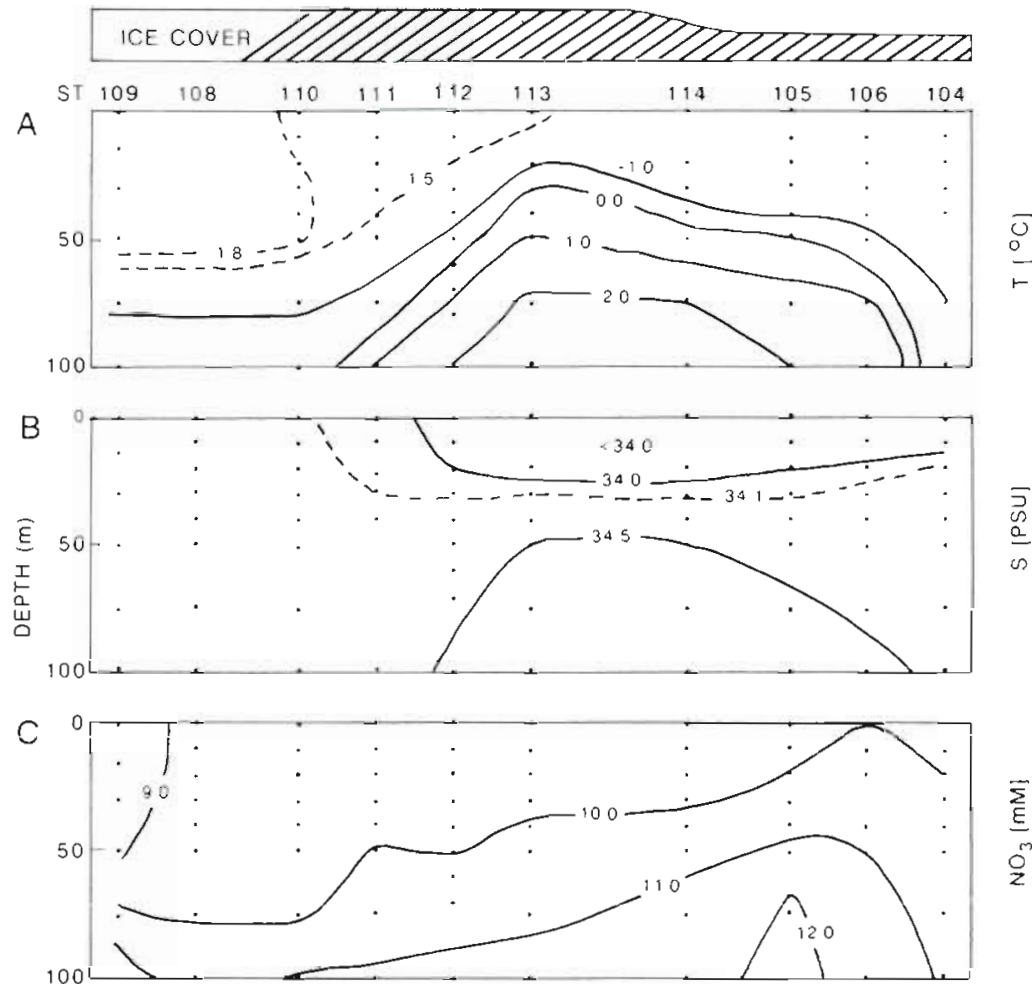

D

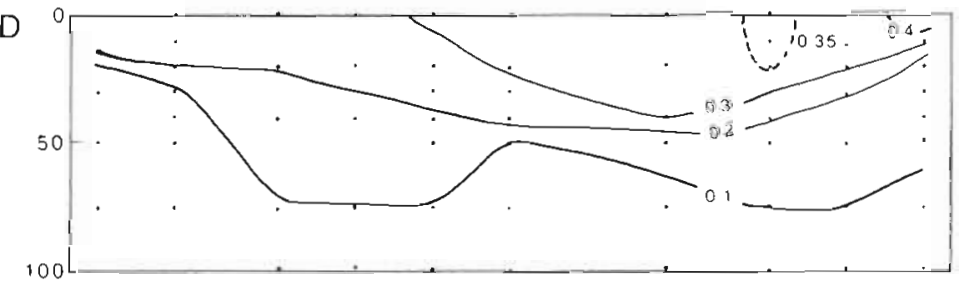

\section{E}
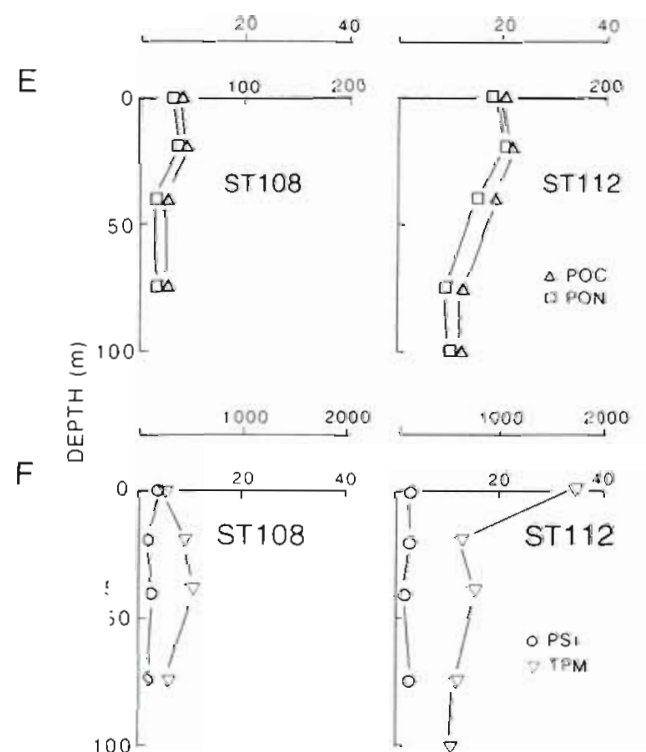

Fig. 5. Variability of (A) temperature, (B) salinity, (C) nitrate and (D) chl a in the upper $100 \mathrm{~m}$ of Transect III. Also shown are vertical profiles of (E) POC and PON, and (F) TPM and PSi recorded down to $20-25 \mathrm{~m}$ depth Increased concentrations of suspended POC (213 to $320 \mathrm{mg} \mathrm{m}^{-3}$ ) and PON (34 to $60 \mathrm{mg} \mathrm{m}^{-3}$ ) were found in the upper $25 \mathrm{~m}$ at Stns 124.2 and 126. While Stns 124.3 and 124.2 had POC and chl a maxima in the surface water, Stn 126 had maxima between 25 and $30 \mathrm{~m}$ depth. The highest concentration of suspended chl a was recorded at Stn 126 (>4 $\mathrm{mg} \mathrm{m}^{-3}$ ). The nutrient concentrations in the stratified water influenced by ice melt were clearly reduced due to phytoplankton growth (Fig. 6)

\section{Vertical flux of particulate matter}

Open water (Transect I). The highest sedimentation rate of TPM in the open water was recorded at Stn 78 (250 $\mathrm{mg} \mathrm{m}^{2} \mathrm{~d}^{-1}$ ) (Fig. 7), about 3.5 times higher than the rate at $\operatorname{Stn} 81$ (70 $\mathrm{mg} \mathrm{m}^{-2} \mathrm{~d}^{-1}$ ). The sedimentation rates of POC, PON and PSi were low and varied slightly $(25-30,4-5$ and 4-5 $\mathrm{mg} \mathrm{m}^{-2} \mathrm{~d}^{-1}$, respectively). The increased sedimentation of TPM at Stn 78 was probably due to inorganic material since there was no similar rise in POC or PON sedimentation rates. The sedimentation rates of algal cells were low at $\operatorname{Stn} 78$ compared to Stn 81 (Tables 2 \& 3) The sedimented cells consisted mainly of flagellates, dinoflagellates and oligotrich ciliates. The elevated sedimentation rates of cells at Stn 81 were mainly due to pennate diatoms. This tendency is not reflected in the sedimentation rate of chl $a$, which was equivalent at Stns 78 and $81\left(60 \mu \mathrm{g} \mathrm{m}^{-2} \mathrm{~d}^{-1}\right)$. Generally speaking, sedimentation rates of chl a were low (Fig. 7). Sedimentation rates of phaeopigments were higher than of chl $a$, and twice as high at Stn 78 $\left(201 \mu \mathrm{g} \mathrm{m}^{-2} \mathrm{~d}^{-1}\right)$ as at Stn $81\left(97 \mu \mathrm{g} \mathrm{m}^{-2}\right.$ $\mathrm{d}^{-1}$ ). The sedimented material was dominated by unidentifiable detritus and faecal pellets (Tables $4 \& 5$ ).

Multi-year ice. The highest sedimentation rates of TPM, POC and phaeo during the investigation were recorded at the northernmost Stn 108 
(1650, 76 and $0.4 \mathrm{mg} \mathrm{m}^{-2} \mathrm{~d}^{-1}$, respectively; Fig. 7). The other stations in this area (101, 112 and 105) were characterised by some of the lowest sedimentation rates found in the present investigation (145-185 and $17-26 \mathrm{mg} \mathrm{m}^{-2} \mathrm{~d}^{-1}$ for TPM and POC, respectively). The sedimentation rates of PON were low at all stations (2 to $3 \mathrm{mg} \mathrm{m}^{-2} \mathrm{~d}^{-1}$ ) and varied less between the stations than did POC and TPM.

The dominant group of sedimented algae at Stn 108 consisted of naked and thecate dinoflagellates. Some of the dinoflagellates were identified as heterotrophic (Pronoctiluca sp. and Amphidinium sp.; data not shown). The ice algae Melosira arctica (both resting spores and vegetative cells, $\sim 50 / 50$; data not shown) and unidentified pennate algae were found in the sedimented material at all stations covered with multi-year ice, and dominated the algal material at Stns 101. 112 and 105. But algae were not important for the total carbon flux at any of the stations in multi-year ice (Table 5), except at Stn 105. Stn 105 had the second highest chl a sedimentation rate during this investigation $\left(125 \mu \mathrm{g} \mathrm{m}^{-2} \mathrm{~d}^{-1}\right)$ and was the only station covered with multi-year ice which had higher sedimentation rates of chl a than of phaeopigment. This suggests that the material sinking here was fresher than at the other stations in Transects II and III. The microscopic examinations of the sedimented material from stations in Transects II and III indicated that sedimentation of faecal pellets was more important for vertical flux than sinking algae at all stations (Table 5). But algae contributed more to vertical flux at Stn 105 than at the other stations.

Marginal ice zone. Str 124 was characterised by high sedimentation rates of TPM and POC (303 and $47 \mathrm{mg} \mathrm{m}^{-2} \mathrm{~d}^{-1}$, respectively) and had the highest sedimentation rate of chl a (952 $\mu \mathrm{g} \mathrm{m}^{-2} \mathrm{~d}^{-1}$ ) during the investigaiion (Fig. F). Fragilanopsis sp. and Chaetoceros socialis dominated the sedimented cells at $\mathrm{Stn}$ 124. The
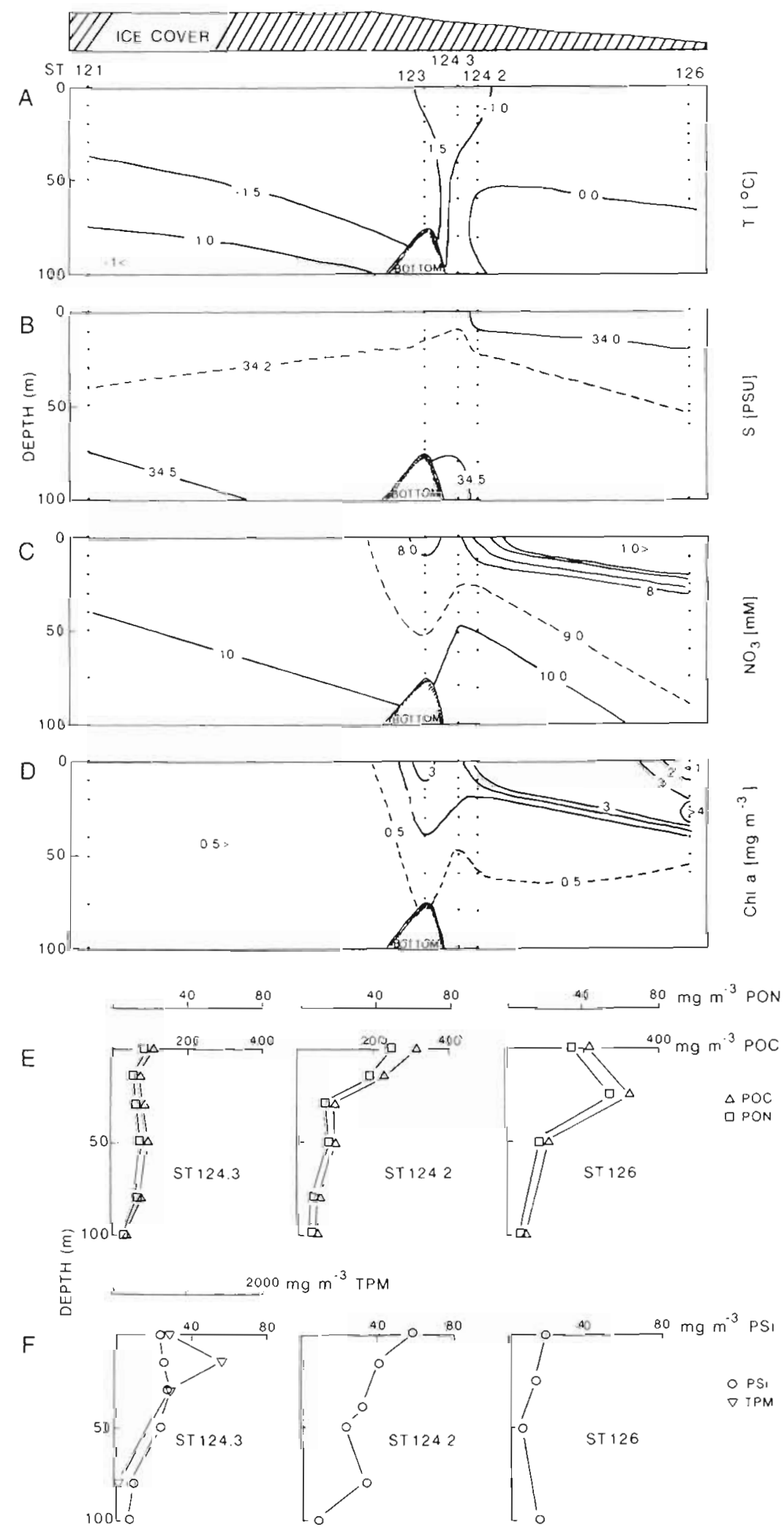

Fig. 6. Variability of (A) temperature, (B) salinity, (C) nitrate and (D) chl a in the upper $100 \mathrm{~m}$ of Transect IV. Also shown are vertical profiles of (E) POC and PON, and $(F)$ TPM and PSi 


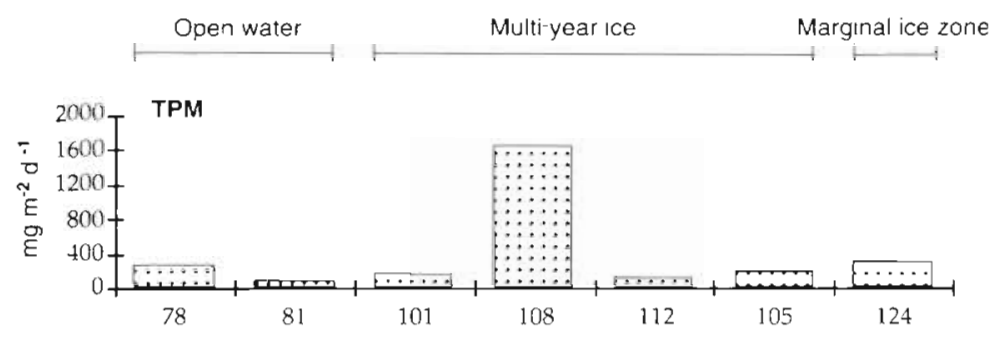

phytoplankton cell sedimentation rate here was 10 to 100 times higher compared to the other stations (Tables $2 \& 3$ ). The importance of sinking diatoms and, in particular, resting spores of $C$. socialis at $\operatorname{Stn} 124$ was by far greater than at any of the other stations (Table 5). The sedimentation rate of faecal pellets (Table 4) was comparable to other stations.
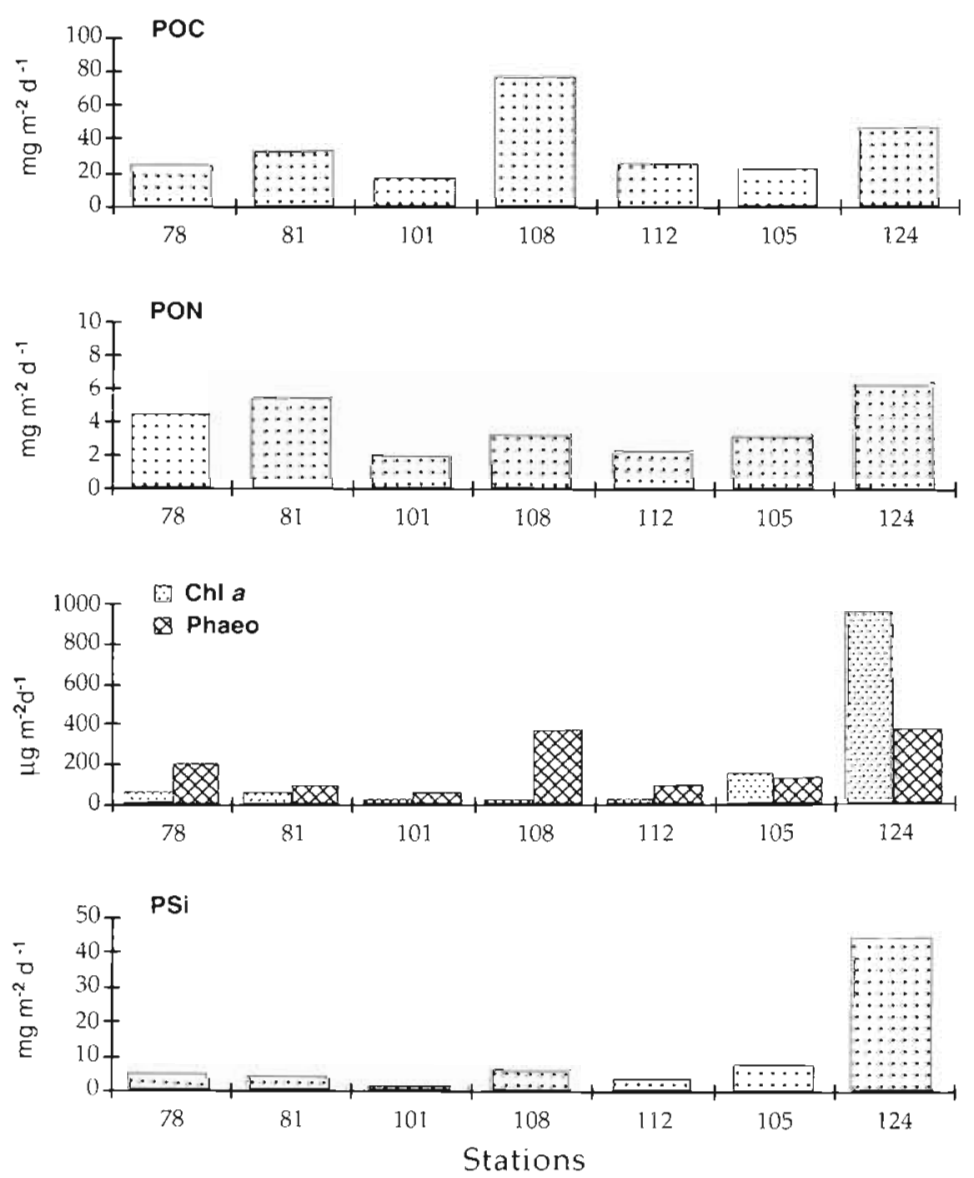

Fig. 7. Sedimentation rates of TPM, POC, PON, PSi $\left(\mathrm{mg} \mathrm{m}^{-2} \mathrm{~d}^{-1}\right)$, chl a

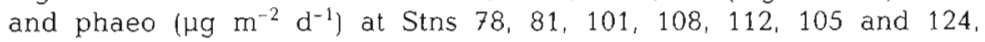
respectively

\section{Biochemical composition of sedimenting matter and relative contribution of phytoplankton cells and faecal pellets}

In the open water off Transect I, POC/PON ratios were lowest and close to the Redfield ratio (6.2 and 6.9) (Table 6). The POC/PON ratios in transects covered by multi-year sea ice were clearly higher, but also more variable. The sedimented material at Stn 108 had a very high POC/PON ratio (about 27). Stns 101 and 112 had lower, but still high, POC/PON ratios (10 and 13). The sedimented material at Stns 105 and 124 had a lower POC/PON ratio ( 7.7 and 8.3 respectively), indicating fresher material compared to the other icecovered stations.

The average $\mathrm{POC} / \mathrm{chl}$ a ratio of about 2000 in sedimented material at stations in Transects I to III (except Stn 105; Table 6) emphasises that fresh phytoplankton played a minor role in the vertical carbon flux at these stations. The chl a/phaeo ratios were $<1$ at the same stations, indicating influence of herbivory. In the southern part of Transect III (Stn 105) and in Transect IV (Stn 124) relatively low POC/chl a ratios of 105 and 50, respectively, were recorded in the sedimented matter. This indicates an

Table 2. Sedimentation rate of different cell classes (no. $\mathrm{m}^{-2} \mathrm{~d}^{-1}$ ) at the different stations

\begin{tabular}{|c|c|c|c|c|c|c|c|}
\hline & \multicolumn{2}{|c|}{ Transect I } & \multirow{2}{*}{$\begin{array}{l}\text { Transect II } \\
\text { Stn } 101\end{array}$} & \multirow[b]{2}{*}{ Stn 108} & \multicolumn{2}{|l|}{ Transect III } & \multirow{2}{*}{$\begin{array}{c}\text { Transect IV } \\
\text { Stn } 124\end{array}$} \\
\hline & Stn 78 & $\operatorname{Stn} 81$ & & & Stn 112 & $\operatorname{Stn} 105$ & \\
\hline Centric diatoms & - & $3.20 \times 10^{3}$ & $1.88 \times 10^{4}$ & $1.37 \times 10^{5}$ & $3.70 \times 10^{5}$ & $6.52 \times 10^{5}$ & $1.77 \times 10^{6}$ \\
\hline Chaetoceros socialis & - & - & - & & - & - & $1.93 \times 10^{8}$ \\
\hline Pennate diatoms & - & $4.10 \times 10^{6}$ & $1.75 \times 10^{6}$ & $2.64 \times 10^{4}$ & $4.40 \times 10^{5}$ & $3.44 \times 10^{6}$ & $1.65 \times 10^{7}$ \\
\hline Dinoflagellates & $6.04 \times 10^{5}$ & $8.30 \times 10^{4}$ & $1.29 \times 10^{4}$ & $9.52 \times 10^{5}$ & $1.94 \times 10^{4}$ & $2.34 \times 10^{3}$ & $8.80 \times 10^{4}$ \\
\hline Flagellates & $1.27 \times 10^{5}$ & $1.21 \times 10^{5}$ & $5.82 \times 10^{6}$ & $6.29 \times 10^{6}$ & - & - & $2.10 \times 10^{7}$ \\
\hline Ciliates & $3.74 \times 10^{3}$ & $1.01 \times 10^{4}$ & $4.00 \times 10^{3}$ & $3.34 \times 10^{4}$ & $2.59 \times 10^{2}$ & - & - \\
\hline Total & $7.35 \times 10^{5}$ & $4.27 \times 10^{7}$ & $7.61 \times 10^{6}$ & $7.44 \times 10^{6}$ & $8.30 \times 10^{5}$ & $4.09 \times 10^{6}$ & $2.32 \times 10^{8}$ \\
\hline
\end{tabular}


Table 3. Sedimentation rate of particulate phytoplankton carbon ( $P P C)\left(\mathrm{mg} \mathrm{m}^{-2} \mathrm{~d}^{-1}\right)$ at the investigated stations. Also shown is the $\mathrm{PPC} / \mathrm{chl}$ a ratio in the sedimented material (ciliates not included)

\begin{tabular}{|lccccccc|}
\hline & \multicolumn{2}{c}{ Transect I } & Transect II & & \multicolumn{2}{c}{ Transect III } & Transect IV \\
& Stn 78 & Stn 81 & Stn 101 & Stn 108 & Stn 112 & Stn 105 \\
\hline Centric diatoms & - & 0.001 & 0.013 & 0.08 & 0.193 & 0.328 & - \\
Chaetoceros socialis & - & - & - & - & - & 0.20 \\
Pennate diatoms & - & 0.44 & 0.175 & 0.001 & 0.002 & 0.413 & 0.73 \\
Dinoflagellates & 0.010 & 0.007 & 0.005 & 0.387 & 0.037 & 0.001 & - \\
Flagellates & 0.0002 & 0.001 & 0.012 & 0.004 & - & -0.01 \\
Ciliates & 0.006 & 0.006 & 0.002 & 0.08 & 0.000 & - \\
Total & 0.016 & 0.545 & 0.207 & 0.552 & 0.232 & 0.742 & 2.47 \\
PPC/chl a & 0.20 & 7.6 & 12.8 & 18.2 & 12.2 & 4.9 & 2.6 \\
\hline
\end{tabular}

Table 4. Volume of sedimented faecal pellets $\left(\mu \mathrm{m}^{3} \mathrm{~m}^{-2} \mathrm{~d}^{-1}\right)$ and amount of sedimented faecal pellet carbon (FPC). Also shown is the $\mathrm{FPC}$ /phaeo ratio in the sedimented material

\begin{tabular}{|lccccccc|}
\hline & \multicolumn{2}{c}{ Transect I } & Transect II & & Transect III & Transect IV \\
& Stn 78 & Stn 81 & Stn 101 & Stn 108 & Stn 112 & Stn 105 & Stn 124 \\
\hline Faecal pellet volume & $1.96 \times 10^{11}$ & $4.04 \times 10^{10}$ & $2.92 \times 10^{10}$ & $3.88 \times 10^{10}$ & $2.35 \times 10^{10}$ & $5.78 \times 10^{10}$ & $4.45 \times 10^{10}$ \\
FPC $\left(\mathrm{mg} \mathrm{m}^{-2} \mathrm{~d}^{-1}\right)$ & 12.0 & 2.5 & 1.4 & 1.5 & 0.9 & 2.2 & 1.7 \\
FPC/phaeo & 58.1 & 25.4 & 24.4 & 4.0 & 9.4 & 17.6 & 4.6 \\
\hline
\end{tabular}

Table 5. Contribution of particulate phytoplankton carbon (PPC) and faecal pellet carbon (FPC) to particulate organic carbon (POC) sedimentation rates

\begin{tabular}{|rcc|}
\hline Station & \% PPC of POC & $\%$ FPC of POC \\
\hline 78 & 0.07 & 51 \\
81 & 1.40 & 8 \\
101 & 1.20 & 8 \\
108 & 0.72 & 2 \\
112 & 0.90 & 3 \\
105 & 3.37 & 10 \\
124 & 5.60 & 4 \\
\hline
\end{tabular}

increased importance of phytoplankton-derived matter closer to the residing ice edge. The relative influence of herbivory was also noticeably lower at these stations, as reflected by chl a/phaeo ratios between 1.2 and 2.55 .

The increased importance of algal matter at Stns 105 and 124 was further confirmed by the higher contribution of PPC to the vertical carbon flux at these stations ( 3.3 and $5.6 \%$, respectively). Table 5 shows that the PPC content of the sinking POC was generally lower at the other stations, in most cases around $1 \%$. In comparison, the contribution of faecal pellets to the vertical fiux of $\mathrm{POC}$ was iar greater at these stations. Stn 124 was the only station during this investigation where the contribution of PPC was higher than that of FPC
(Table 5). On average about $12 \%$ of the vertical POC flux was due to FPC. By far the greatest contribution of FPC to the vertical POC flux was found in the open water at $\operatorname{Stn} 78(51 \%)$, while the contribution at the other stations was more variable (2 to $10 \%$, average about $6 \%$ ).

\section{DISCUSSION}

The sediment trap technology used in this, as in any other study, is far from perfect. The technique has been disputed in general (e.g. GOFS 1989, Buesseler 1991), but the obvious weaknesses in the present investigation are (1) the relatively short and varying sampling times, (2) the underestimation of vertical flux in the cone-shaped part of the sediment trap (Taguchi et al. 1993) and (c) the potential disturbance by the ice breaker of the under-ice flora and fauna. The latter is probably less important, since only small amounts of released ice algae were found in the sedimented material and the traps at $100 \mathrm{~m}$ depth sample particles from a larger area than that influenced by the ice breaker. Given these limitations, the present results should be considered only indicative of the quantities and composition of the sinking particulate matter.

The magnitude of vertical flux is determined by the new production, phytoplankton bloom development and species composition as well as the influence of 
Table 6. POC/PON, POC/chl a, chl a/phaeo, PSi/phaeo and PSi/chl a ratios of the sedimented matter

\begin{tabular}{|c|c|c|c|c|c|c|}
\hline Transect & Station & $\begin{array}{c}\text { POC/PON } \\
\text { (a/a) }\end{array}$ & $\begin{array}{c}\mathrm{POC} / \mathrm{chl} \mathrm{a} \\
(\mathrm{w} / \mathrm{w})\end{array}$ & $\begin{array}{c}\text { chl a/phaeo } \\
(w / w)\end{array}$ & $\begin{array}{c}\text { PSi/phaeo } \\
(w / w)\end{array}$ & $\begin{array}{c}\mathrm{PSi} / \mathrm{chl} a \\
(\mathrm{w} / \mathrm{w})\end{array}$ \\
\hline I & $\begin{array}{l}78 \\
81\end{array}$ & $\begin{array}{l}6.2 \\
6.9\end{array}$ & $\begin{array}{r}3930 \\
540\end{array}$ & $\begin{array}{l}0.03 \\
0.61\end{array}$ & $\begin{array}{l}22 \\
40\end{array}$ & $\begin{array}{r}840.90 \\
65.87\end{array}$ \\
\hline II & 101 & 9.9 & 1110 & 0.25 & 27 & 95.03 \\
\hline III & $\begin{array}{l}108 \\
112 \\
105\end{array}$ & $\begin{array}{r}26.6 \\
13.0 \\
7.7\end{array}$ & $\begin{array}{r}2980 \\
1360 \\
150\end{array}$ & $\begin{array}{l}0.07 \\
0.20 \\
1.22\end{array}$ & $\begin{array}{l}17 \\
36 \\
59\end{array}$ & $\begin{array}{r}244.43 \\
181.63 \\
48.17\end{array}$ \\
\hline IV & 124 & 8.3 & 50 & 2.55 & 118 & 46.29 \\
\hline
\end{tabular}

planktonic heterotrophs on algae, faecal pellets and detritus. In non-ice-covered waters and areas under the influence of Atlantic water, stratification develops slowly and is mainly influenced by solar radiation and turbulence. Spring blooms can take place even under non-stratífied condiliuns in sub-polar and polar environments (Townsend et al. 1992, Eilertsen 1993). Consequently the phytoplankton development in waters not covered by sea ice is delayed and slower compared to that in the MIZ (Skjoldal \& Rey 1989). This was observed in Transect I. The biomass in the water column was dominated by small flagellates and ciliates (G. Socal \& J. Wiktor pers. comm.). These cells have low sinking rates (Smayda 1970) and, as a consequence, such communities contribute little to the vertical flux of organic matter (Kiørboe 1993). Our data reflected such a scenario: vertical flux of organic matter was low, especially vertical flux of phytoplankton. Faeces of mesozooplankton were the main vehicle for the vertical export of organic matter along Transect $I$, in particular at Stn 78 (Table 4), which indicated an influence of mesozooplankton grazing. The high vertical flux of PSi (Fig. 7) and absence of diatom cells (Table 2) in the sedimented material at Stn 78 indicate that the major diet of zooplankton must have been diatoms. The low suspended concentrations of diatoms could have been due to a high grazing pressure on this part of the plankton community. Mesozooplankton biomass along the transect was dominated by Calanus finmarchicus and Oithona sp. Mesozooplankton concentrations were highest at Stn 81, mainly due to Oithona sp. (H. González \& G. Fransz pers. comm.). Experiments carried out during the cruise indicated that Oithona sp. is coprophagous (González \& Smetacek 1994), and the elevated concentrations of this species at Stn 81 may have been responsible for the lower vertical flux of faecal pellets here compared to Stn 78 .

In ice-covered environments, water column stability due to melting ice, the depth of the stratified surface water and photosynthetic active radiation (PAR) control the size and development of the spring bloom (Sakshaug \& Holm-Hansen 1984, Sakshaug \& Skjoldal
1989). Before the ice cover melts or recedes from an area, planktonic primary production is light limited and develops slowly. Both Transects II and III experienced heavy ice cover, and the low chl a concentrations and relatively higher POC concentrations imply that the suspended biomass in these transects was not dominated by phytoplankton. Nutrient concentrations indicated that some primary production had taken place along Transect II, which probably reflects increased PAR in an earlier period. However, a concomitant increase of suspended biomass was not recorded. Deterioration of light conditions due to new advances of the ice edge or closing of wakes might have limited or stopped a further development of the bloom. At the time of the investigation the phytoplankton was probably light-limited due to an ice thickness of 2 to $4 \mathrm{~m}$ (Inall \& Parker 1992). The phytoplankton community structure was similar to that at Stn 78 in Transect I, with dino- and nanoflagellates dominating (G. Socal \& J. Wiktor pers. comm.), implying a low potential for cell sedimentation. Low sedimentation of phytoplankton and ice algae was actually observed throughout the transects, and faecal pellets were the more important vehicle for vertical carbon flux in these ice-covered waters (Table 6). The heterotrophic dinoflagellates observed in the sedimented material of Stn 108 could have been sinking in association with aggregates (Alldredge \& Silver 1988). When more PAR was available under a thinner ice cover such as that at Stn 105, suspended chlorophyll concentrations increased, resulting in a higher sedimentation rate of chl a and algae (Fig. 7).

Sea ice in the Arctic Ocean frequently contains significant amounts of inorganic matter (Vinje \& Kvambekk 1991). Also, terrestrial matter transported by rivers to the Siberian Shelf is frozen into sea ice and is transported by the Transpolar Drift into the area north of Spitsbergen and the Fram Strait (Reimnitz et al. 1994). When this ice melts it releases the particulate matter, giving rise to increased vertical flux of TPM and terrestrial organic matter This hypothesis is supported by observations of terrestrial material dominat- 
ing the sediments below the Transpolar Drift (Stein et al. 1994). Stn 108 revealed the highest TPM and POC sedimentation rates of the present investigation (Fig. 7). A high POC/PON ratio of 26.6 indicates that the sinking matter could not have been due to fresh marine material, as the POC/PON ratio of this matter usually varies between 7 and 15 in the central Barents Sea (Wassmann 1989) and in fjords (Wassmann 1991). The vertical flux at Stn 108 probably reflects melting ice from the Transpolar Drift and a resulting release of particulate content derived from the Laptev Sea. The sedimentation rates of TPM were similar to those found by Hebbeln \& Wefer (1991) at depth during periods of multi-year sea-ice melting in the Fram Strait. From our visual observations during the cruise it can be assumed that the particulate content of sea ice had a patchy distribution. Also, the release of particulate matter from the ice can be irregular. This seems to be reflected by the great variability in sedimentation rates along the transects covered by multi-year ice.

The withdrawal and melting of sea ice gives rise to a strong stabilisation of the surface water in the MIZ of the Barents Sea (Slagstad 1985) and, together with the increase in PAR, creates very favourable conditions for a strong and rapid spring bloom (Rey \& Loeng 1985). This scenario corresponds to the situation in Transect IV, which was characterised by extensive ice-coverage in the north and melting ice in the south (i.e. the transect covered the MIZ). The typical sequence of the ice edge bloom in space and time (Sakshaug \& Skjoldal 1989 ) is clearly indicated by the high chl a concentrations in the upper part of the water column in the centre of the transect, and a deep chlorophyll maximum close to the nutricline in the southern part of the transect (Fig. 6). This was further confirmed by the phytoplankton species composition, with Fragilariopsis sp. and Chaetoceros socialis dominating the biomass of the water column (G. Socal \& J. Wiktor pers. comm.). These diatoms are typical during the spring bloom in the Barents Sea (Rey \& Loeng 1985, Syvertsen 1991) and marginal ice zones in general (Horner 1989, Kang $\&$ Fryxell 1992). The high chl a and nutrient concentrations indicated an early, healthy bloom. However, resting spores of $C$. socialis point to a deterioration of the living conditions of diatoms (Rey \& Skjoldal 1987. Davis et al. 1980). Another common spring bloom species in the Barents Sea, the haptophyte Phaeocystis pouchetii (e.g. Wassmann et al. 1990), was also found, but only in low concentrations (G. Socal \& J. Wiktor pers. comm.)

The rapid development of the spring bloom in the MIZ of the Barents Sea typically decouples zooplankton and prevents significant grazing (Eilertsen et al. 1989), and a strong pulse of ungrazed or partly grazed material follows after nutrient limitation sets in (Wass- mann et. al 1991). The upper part of the water column at Stn 124 was not entirely nutrient depleted, but the vertical fluxes of phytoplankton cells and chl a at this station were the highest in the survey. The moderate concentration of mesozooplankton at this site (González \& Smetacek 1994) was obviously not enough to produce a grazing pressure which could control the vernal bloom. This was reflected in the highest vertical export of PPC found in this investigation. Thus Transect IV reflects the typical spring dynamics of the Barents Sea MIZ, characterised by extensive phytoplankton blooms and vertical export of ungrazed phytoplankton, as described by conceptual (Sakshaug \& Skjoldal 1989) and numerical (Wassmann \& Slagstad 1993) models

The particulate silicate content of the sedimented matter was quite high at all stations despite the low number of diatom cells at some of the stations. At Stn 78, for example, no diatom cells were found in the sedimented material, but a sedimentation rate of $5 \mathrm{mg}$ PSi m${ }^{-2} \mathrm{~d}^{-1}$ was recorded. This probably reflects strong, selective mesozooplankton grazing pressure on diatoms. Particulate silicate passes more or less unchanged through the gut of zooplankton (Tande \& Slagstad 1985), and faecal pellets can be an important particulate silicate source in sedimented matter of polar waters (Gersonde \& Wefer 1987). Faecal pellets seem, therefore, to be the most prominent source of sedimented PSi, in particular at Stn 78, which experienced the highest faecal pellet sedimentation rate (Table 4). This is also reflected by the PSi/phaeo ratio of the sedimented matter, which varied little $(46 \pm 76 \%)$ along all transects while that of PSi/chl a varied greatly $(217 \pm 130 \%$ ) (Table 6 ). In the MIZ at Stn 124 the PSi sedimentation rate was highest (Table 6) due to a combination of direct deposition of ungrazed diatoms, especially Chaetoceros socialis with relatively strongly silicified resting spores (e.g. Rey \& Skjoldal 1987) and faecal pellets.

A modest variation in faecal pellet sedimentation

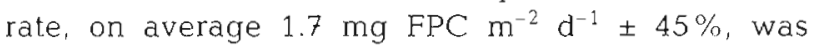
recorded at 6 of 7 stations (Table 4). This could be caused by the following factors: (1) the faecal pellet production rate of the mesozooplankton community differed little despite the differences in community structure, environmental conditions and availability of food; or (2) an increased vertical flux of faecal pellets was counteracted by zooplankton-mediated processes such as coprophagy. Although faecal pellets were the most important identified contributor to the vertical flux, microscopic investigation revealed large amounts of detritus in the sedimented material at all stations, which may reflect disintegration of faecal pellets. The vertical flux of faecal pellets supports the observation of González \& Smetacek (1994) that the abundant 
cyclopoid copepod Oithona $\mathrm{sp}$. coincides with a removal of suspended faecal pellets, suggesting that processes like coprophagy resulted in small-sized suspended particulate organic matter and nutrients in icecovered areas. Less than $15 \%$ of the POC flux could be accounted for at all stations except Stn 78, and more precise investigations of the sources of the detrital fraction of sedimented material would require access to biogeochemical analytical techniques. Despite the limited assessment of the origin of sedimenting organic matter, our observations indicate that faecal pellets played a major role in the vertical flux north off Spitsbergen during spring and that sedimented detritus probably derived from the feeding activity of zooplankton.

Experience from the Barents Sea shelf (e.g. Wassmann \& Slagstad 1993) and other ice-covered shelf areas (e.g. Tremblay et al. 1989) has so far indicated a significant loss associated with the spring bloom. In contrast, the low vertical carbon flux rates in spring in the present study point to the possibility that major amounts of algal carbon do not reach the sediments and deeper waters in most of the ice-covered areas off northern Spitsbergen. The implied recycling of phytoplankton- and ice-algal-derived matter in the upper layers greatly diminishes the possible importance of algae in carbon export to the deep ocean and $\mathrm{CO}_{2}$ sequestration. A storage of $\mathrm{CO}_{2}$ at mid-water depths off northern Spitsbergen is likely during spring and summer. This $\mathrm{CO}_{2}$ may be released to the atmosphere during autumn and winter, but extensive ice-coverage and strong stratification can prevent that release (Yager et al. 1995), providing a small, negative feedback to atmospheric $\mathrm{CO}_{2}$. Despite the rapid recycling of carbon in the upper layer, ice cover and stratification may contribute to the role of the Arctic Ocean as a true sink of atmospheric $\mathrm{CO}_{2}$, as suggested by Anderson et al. (1990).

\section{CONCLUSION}

Compared to the Barents Sea shelf, which is influenced by Atlantic water, the vertical flux of particulate matter in the WSC was low and phytodetritus, faecal pellets and detritus dominated. Ecological knowledge from the Barents Sea shelf, therefore, cannot be directly transferred to the shelf west and northwest of Spitsbergen.

In the multi-year ice-covered waters north of Spitsbergen, terrestrial material released from melting ice seemed to be an important component of the vertical flux of organic matter. In addition, faecal pellets played a more important role in the vertical carbon flux than phytoplankton. An inverse relationship between zoo- plankton density (mainly Oithona sp.) and faecal pellet flux suggests that zooplankton-mediated processes such as coprophagy were of significance for retaining particulate matter in the upper water column. Ice algae and phytoplankton contributed less than did faecal pellets to the vertical flux in the multi-year ice-covered waters north of Spitsbergen.

The conspicuous vertical flux of ungrazed phytoplankton and ice algae in the MIZ contrasted with the other areas and the bloom was obviously controlled by zooplankton only to a small degree.

This study indicates that phytoplankton blooms and vertical flux in the various ice-covered areas around Spitsbergen can differ greatly. Even in multi-year icecovered areas, vertical carbon flux differs as a function of the origin of the ice, its terrestrial matter content, the extent of the sea ice and the under-ice flora and fauna The general picture is (1) that the vertical flux had a low pigment content and the contribution of algae was low (PPC $<5 \%$ of POC), (2) that the chl a/phaeo ratios were low (mainly <1) and the FPC/POC ratios high, and (3) that the organic matter was degraded (POC) chl a ratios $>150$ ). This implies a dominance of faecal matter and detritus, with minor contributions of algae under spring conditions. In contrast to the adjoining shelf areas characterised by seasonal and inter-annual variation of the MIZ, material fluxes in the deeper parts of the Arctic Ocean seem to be effectively controlled by grazers or allochthonous sources.

Acknowledgements. We thank the captain and the crew of RV 'Polarstern' as well as the participants of the cruise for support during the investigation. A special thanks to Guiseppe Civitarese and Anna Luchetta for nutrient data and Gina Owrid for help with chl a analyses. Liss Olsen and Froydis Strand prepared the final figures. Thanks to Victor Smetacek and two reviewers for comments on the manuscript. The investigation was supported by the European Science Foundation and the Norwegian Research Council and is a contribution from the Norwegian Research Programme of North Norwegian Coastal Ecology (MARE NOR).

\section{LITERATURE CITED}

Alldredge AL, Silver MW (1988) Characteristics, dynamics and significance of marine snow. Prog Oceanogr 20:41-82

Anderson LG, Dyrssen D, Jones EP (1990) An assessment of the transport of atmospheric $\mathrm{CO}_{2}$ into the Arctic Ocean. $\mathrm{J}$ Geophys Res 95:1703-1711

Bathmann UV, Fischer G, Müller PJ, Gerdes D (1991) Shortterm variations in particulate matter sedimentation of Kapp Norvegia, Weddell Sea, Antarctica: relation to water mass advection, ice cover, plankton biomass and feeding activity. Polar Biol 11:185-195

Bathmann UV, Peinert R, Noji TT, Bodungen B von (1990) Pelagic origin and fate of sedimenting particles in the Norwegian Sea. Prog Oceanogr 24:117-125

Bodungen $B$ von, Antia A, Bauerfeind E, Haupt $O$, Koeve W, Machado E, Peeken I, Peinert R, Reitmeier S, Thomasen 
C, Voss M, Wunsch M, Zeller U, Zeitzschel B (1995) Pelagic processes and vertical flux of particles: an overview of a long-term comparative study in the Norwegian Sea and Greenland Sea. Geol Rundschau 84:11-27

Buesseler KO (1991) Do upper-ocean sediment traps provide an accurate record of particle flux? Nature 353:420-423

Carey AG Jr (1987) Particle flux beneath fast ice in the shallow southwestern Beaufort Sea, Arctic Ocean. Mar Ecol Prog Ser 40:247-257

Davis CO, Hoolibaugh JT, Seibert DLR, Thomas WH (1980) Formation of resting spores by Leptocylindrus danicus (Bacillariophyceae) in a controlled experimental ecosystem. J Phycol 16:296-302

Edler L (1979) Recommendations for marine biological studies in the Baltic Sea-phytoplankton and chlorophyll. Baltic Mar Biol 5:1-38

Eilertsen HC (1993) Spring blooms and stratification. Nature 363:24

Eilertsen HC, Tande KS, Hegseth EN (1989) Potential herbivorous copepods for regulating the spring phytoplankton bloom in the Barents Sea. Rapp PV Réun Cons Int Explor Mer 188:154-163

Fischer G, Fütterer D, Gersonde R, Honjo S, Ostermann D, Wefer G (1988) Seasonal variability of particle flux in the Weddell Sea and its relationship to ice cover. Nature 335: $426-428$

Gersonde R, Wefer G (1987) Sedimentation of biogenic siliceous particles in Antarctic Waters from the Atlantic Sector. Mar Micropaleon 11:311-332

GOFS (US Global Ocean Flux Study) (1989) Sediment trap technology and sampling. Report of the US GOFS working group of sedimenting trap technology and sampling, Woods Hole

González H, Smetacek V (1994) The possible role of the cyclopoid copepod Oithona in retarding vertical flux of the zooplankton faecal material. Mar Ecol Prog Ser 113: $233-246$

Grasshoff K (1976) Methods of sea water analysis. Verlag Chemie, Weinheim

Hargrave BT, Bodungen B von, Stoffyn-Egli P, Mudie PJ (1994) Seasonal variability in particle sedimentation under permanent ice cover in the Arctic Ocean. Cont Shelf Res 14:279-293

Hebbeln N, Wefer G (1991) Effects of ice coverage and icerafted material on sedimentation in the Fram Strait. Nature 350:409-411

Holm-Hansen O, Lorenzen CJ, Holmes RW, Strickland JDH (1965) Fluorometric determination of chlorophyll. J Cons Perm Int Explor Mer 30:3-15

Honjo S, Manganini ST, Karowe A, Woodward BL (1987) Particle fluxes, North-Eastern Nordic Seas: 1983-1986. Woods Hole Oceanographic Inst Tech Rept WHOI-87-17, Woods Hole

Honjo S, Manganini ST, Wefer G (1988) Annual particle flux and a winter outburst of sedimentation in the northern Norwegian Sea. Deep-Sea Res 35:1223-1234

Horner R (1989) Arctic sea-ice biota. In: Herman Y (ed) The Arctic seas. Van Nostrand Reinhold Company, New York, p 123-146

Hsiao SIC (1987) Sedimentation in Arctic Canada: species composition and biomass of phytoplankton contributed to the marine sediments in Frobiser Bay. Polar Biol 7 : $245-251$

Inall M, Parker P (1992) Sea icc. In: Pachor E (cd) Scicntific Cruise Report of the 1991 Arctic Expedition ARK VIII/2 of RV 'Polarstern' (EPOS II: Study of the European Arctic Shelf, 'SEAS', of the European Science Foundation).
Berichte zur Polarforschung 115, Alfred-Wegener-Institut für Polar und Meeresforschung, Bremerhaven, $\mathrm{p} 43-50$

Iseki K (1981) Vertical transport of particulate organic matter in the deep Bering Sea and Gulf of Alaska. J Oceanogr Soc Jap 37:101-110

Kang SH. Fryxell GA (1992) Fragilariopsis cylindrus (Grunow) Krieger: the most abundant diatom in water column assemblages of Antarctic marginal ice-edge zones. Polar Biol 12:609-627

Kiørboe T (1993) Turbulence, phytoplancton cell size, and the structure of pelagic food webs. Adv Mar Biol 29:2-72

Michel C, Legendre L, Therriault JC, Demers S, Vandevelde T (1993) Springtıme coupling between ice algal and phytoplankton assemblages in Southeastern Hudson Bay, Canadian Arctic. Polar Biol 13:441-449

Nöthıg EM, Bodungen B von (1989) Occurrence and vertical flux of faecal pellets of probably protozoan origin in the southeastern Weddell Sea (Antarctica). Mar Ecol Prog Ser $56: 281-289$

Passow U, Logan BE, Alldredge AL (1994) The role of particulate carbohydrate exudates in the floculation of diatom blooms. Deep-Sea Res 41:335-357

Reimnitz E, Dethleff D, Nürnberg D (1994) Contrasts in Arctic shelf sea-ice regimes and some implication: Beaufort Sea versus Laptev Sea. Mar Geol 119:215-225

Rey $F$, Loeng $H$ (1985) The influence of ice and hydrographic conditions on the development of stress on marine organisms. In: Gray JS, Christiansen ME (eds) Marine biology of polar regions and effect of stress on marine organisms. John Wiley \& Sons Ltd, Chichester, p 49-63

Rey F, Skjoldal HR (1987) Consumption of silica acid below the euphotic zone by sedimenting diatom blooms in the Barents Sea. Mar Ecol Prog Ser 36:307-312

Riebesell U, Schloss I, Smetacek V (1991) Aggregation of algae released from melting sea ice: implications for seeding and sedimentation. Polar Biol 11:239-248

Sakshaug E, Holm-Hansen $O$ (1984) Factors governing the pelagic production in Polar oceans. In: Holm-Hansen $O$, Bolis L, Gilles RG (eds) Marine phytoplankton and productivity. Lecture notes on coastal and estuarine studies No 8. Springer Verlag, New York, p 1-18

Sakshaug E, Skjoldal HR (1989) Life at the ice edge. Ambio $18: 60-67$

Sarmiento JL, Toggweiler JR (1984) A new model for the role of the oceans in determining atmospheric $\mathrm{pCO}_{2}$. Nature 308:621-624

Skjoldal HR, Rey F (1989) Pelagic production and variability of the Barents Sea ecosystem. In: Sherman K, Alexander LM (ed) Biomass and geography of large marine ecosystems. Westview Press, Boulder, CO, p 243-283

Slagstad D (1985) A model of phytoplankton in the marginal sea-ice zone of the Barents Sea. In: Gray JG, Christiansen ME (ed) Marine biology of polar regions and effect of stress on marine organisms. John Wiley \& Sons Ltd, Chichester, p 35-48

Smayda $T(1970)$ The suspension and sinking of phytoplankton in the sea. Oceanogr Mar Biol A Rev 8: 353-4.14

Stein R, Grobe H, Wahsner M (1994) Organic carbon, carbonate, and clay mineral distributions in eastern central Arctic Ocean surface sediments. Mar Geol 119:269-285

Syvertsen EE, (1991) Ice algae in the Barents Sea: types of assemblages, origin, fate and role in the ice-edge phyto-

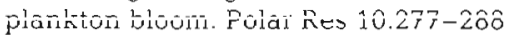

Taguchi S, Saito H, Kasai H (1993) Effect of shape of sediment trap on measurements of vertical flux of particles, preliminary results. Polar Biol 6:1-5 
Takahashi I, Olafsson J, Goddart JG, Chipman DW, Sutherland SC (1993) Seasonal variation of $\mathrm{CO}_{2}$ and nutrients in the high-latitude surface oceans: a comparative study. Global Biogeochem Cycles 7:843-878

Tande KS, Slagstad D (1985) Assimilation efficiency in herbivore organisms - the potential of the ratio method using ${ }^{14} \mathrm{C}$ and biogenic silica as markers. Limnol Oceanogr 30 : 1093-1099

Townsend DW, Keller MD, Sieracki ME, Ackelson SG (1992) Spring phytoplankton blooms in the absence of vertical water column stratification. Nature 360:59-62

Tremblay C. Runge JA, Legendre L (1989) Grazing and sedimentation of ice algae during and immediately after a bloom at the ice-water interface. Mar Ecol Prog Ser 56: $291-300$

Vinje T, Kvambekk $\AA S$ (1991) Barents Sea drift ice characteristics. Polar Res 10:59-68

Wassmann P (1989) Sedimentation of organic matter and sili-

This article was submitted to the editor cate from the euphotic zone of the Barents Sea. Rapp PV Réun Cons Int Explor Mer 188:108-114

Wassmann P (1991) Dynamics of primary production and sedimentation in shallow fjords and polls of Western Norway. Oceanogr Mar Biol A Rev 29:87-154

Wassmann P, Peinert R, Smetacek V (1991) Patterns of production and sedimentation in the boreal and polar Northeast Atlantic. Polar Res 10:209-228

Wassmann P, Slagstad D (1993) Seasonal and annual dynamics of carbon flux in the Barents Sea: a model approach. Polar Biol 13:363-372

Wassmann $P$, Vernet $M$, Mitchell G, Rey F (1990) Mass sedimentation of Phaeocystis pouchetii in the Barents Sea. Mar Ecol Prog Ser 66:186-195

Yager PL, Wallace DWR, Johnson KM, Smith O, Minnett PJ. Deming JW (1995) The Northeast Water Polynia as an atmospheric $\mathrm{CO}_{2}$ sink: a seasonal rectification hypothesis. J Geophys Res 100:4389-4398

Manuscript first received: March 22, 1995

Revised version accepted: December 28, 1995 